\title{
Use of synchrotron medical microbeam irradiation to investigate radiation-induced bystander and abscopal effects in vivo
}

\author{
Cristian Fernandez-Palomo ${ }^{\text {a, * }}$, Elke Bräuer-Krisch ${ }^{b}$, Jean Laissue ${ }^{c}$, Dusan Vukmirovic ${ }^{a}$, \\ Hans Blattmann ${ }^{\mathrm{d}}$, Colin Seymour ${ }^{\mathrm{a}}$, Elisabeth Schültke ${ }^{\mathrm{e}}$, Carmel Mothersill ${ }^{\mathrm{a}}$ \\ a Department of Medical Physics and Applied Radiation Sciences, McMaster University, Hamilton, Ontario L8S 4K1, Canada \\ ${ }^{\mathrm{b}}$ European Synchrotron Radiation Facility, BP 220 6, rue Jules Horowitz, 38043 Grenoble, France \\ ${ }^{\mathrm{c}}$ University of Bern, Hochschulstrasse 4, $\mathrm{CH}-3012$ Bern, Switzerland \\ d Niederwiesstrasse 13C, Untersiggenthal, Switzerland \\ e Department of Radiotherapy, Rostock University Medical Center, Südring 75, 18059 Rostock, Germany
}

\section{A R T I C L E I N F O}

\section{Article history:}

Received 20 December 2014

Received in revised form

6 March 2015

Accepted 9 March 2015

Available online 25 March 2015

\section{Keywords:}

Radiation-induced bystander effects

Synchrotron microbeam radiation

Fischer rats

F98 glioma

\begin{abstract}
A B S T R A C T
The question of whether bystander and abscopal effects are the same is unclear. Our experimental system enables us to address this question by allowing irradiated organisms to partner with unexposed individuals. Organs from both animals and appropriate sham and scatter dose controls are tested for expression of several endpoints such as calcium flux, role of 5HT, reporter assay cell death and proteomic profile. The results show that membrane related functions of calcium and 5HT are critical for true bystander effect expression. Our original inter-animal experiments used fish species whole body irradiated with low doses of X-rays, which prevented us from addressing the abscopal effect question. Data which are much more relevant in radiotherapy are now available for rats which received high dose local irradiation to the implanted right brain glioma. The data were generated using quasi-parallel microbeams at the biomedical beamline at the European Synchrotron Radiation Facility in Grenoble France. This means we can directly compare abscopal and "true" bystander effects in a rodent tumour model. Analysis of right brain hemisphere, left brain and urinary bladder in the directly irradiated animals and their unirradiated partners strongly suggests that bystander effects (in partner animals) are not the same as abscopal effects (in the irradiated animal). Furthermore, the presence of a tumour in the right brain alters the magnitude of both abscopal and bystander effects in the tissues from the directly irradiated animal and in the unirradiated partners which did not contain tumours, meaning the type of signal was different.

(C) 2015 Published by Elsevier Ltd on behalf of Associazione Italiana di Fisica Medica. This is an open access article under the CC BY-NC-ND license (http://creativecommons.org/licenses/by-nc-nd/4.0/).
\end{abstract}

\section{Introduction}

Non-targeted effects including bystander (effects in unirradiated cells receiving signals from irradiated cells) and abscopal effects (effects in unirradiated tissues following irradiation of a different tissue in a distant location) are known to occur following both low and high doses of radiation and other stressors both in vitro and in vivo. Most in vivo data involve shielding part of an animal and are complicated by systemic factors such as blood and endocrine factors, making it difficult to resolve mechanistic questions related for example to the role of the immune system or the inflammatory response in the process [1-4]. While the existence of

\footnotetext{
* Corresponding author. Tel.: +1 (905) 525 9140x21607.

E-mail address: fernancg@mcmaster.ca (C. Fernandez-Palomo).
}

both bystander effects and abscopal effects are widely accepted, they remain poorly understood. By definition abscopal effects occur in vivo, usually as a result of targeted radiotherapy to another part of the body [5,6]. Bystander effects have been demonstrated in vitro in numerous cell lines across all species groups and in vivo in rodent models [7], fish [8,9], amphibians [10] and yeast [11]. In much of the literature, abscopal and bystander effects are thought to share common mechanisms and to be mediated by similar signals $[1,12]$. However most bystander research is conducted using low doses of mainly low LET radiation delivered to the entire organism or cell culture, while abscopal effects are detected following high doses of targeted radiotherapy to precise areas of the body which usually contain tumour tissue $[1,2,13]$. This makes it difficult to ascertain whether common mechanisms are involved or whether both mechanism are related. 
A further limitation of research in the field is that in vivo "bystander" experiments usually use shielding of part of the body to demonstrate effects in non-irradiated areas [14-16]. This means that the hematopoietic, neural, immune and endocrine systems could be irradiated and could either pass through the unirradiated area (blood and endocrine effectors) or share common neuronal connections leading to detection of distant effects. Additionally, scatter and out of field doses may contribute sufficient radiation to trigger bystander effects, which have thresholds in the $2-3 \mathrm{mGy}$ dose range [17-24]. It is unclear whether an animal that received the estimated scatter dose as whole body irradiation, is a sufficient control to cover these possibilities for reasons which will be discussed later in the paper. Clearly there could be confusion in determining separate mechanisms involved in bystander and abscopal effects in vivo.

In the past we have successfully used an approach where nonirradiated companion animals are placed in close proximity to irradiated animals. Our group have conducted several experiments with irradiated fish [25-27] sharing aquarium water with unirradiated fish, and Surinov's group in Russia [28,29] and our group [7] have also demonstrated communication between irradiated mice and their cage mates with subsequent signal expression in the nonirradiated animals. These experiments parallel in vitro "medium transfer" experiments in that the unirradiated animals receiving signals from irradiated animals were never anywhere near the radiation source and never had any part of their bodies exposed to Xrays. This precludes systemic effects due to the circulating blood, or endocrine or neural components being affected by exposure of part of the body to irradiation. The fish experiments involved whole body exposure to very low X-ray doses and confirmed a role of serotonin and calcium in the production of the bystander signal in vivo $[30,31]$ as was seen in vitro [32-34].

The development of microbeam radiation therapy (MRT) using synchrotron generated kilovoltage energy X-rays is based on the concept that sparing of normal tissues will occur in the dose valleys between the peak dose tracks [35-37]. MRT, a still experimental form of spatially fractionated radiotherapy, has been developed for the treatment of small and otherwise intractable brain and spinal cord tumours [38-43]. Bystander effects are thought to play a role in the dose valleys where the absorbed X-ray dose is generally lower than in the peak dose zones by more than one order of magnitude [44-46]. However the precise nature and role of these effects is unclear especially since the valley dose greatly exceeds the threshold of 2-3 mGy established for the induction of bystander signalling processes in low dose in vitro irradiation [22-24]. The current experiments were performed using the biomedical beamline ID17 at the European Synchrotron Radiation Facility (ESRF) in Grenoble as part of a wider study of the use of microbeam and pencil beam therapy in the treatment of malignant brain tumours in small animal models [7,45-49].

Preliminary experiments [7], with normal tumour-free rats, have shown that bystander signals were being communicated from irradiated rats to unirradiated rats. Tissues from the unirradiated rats when cultured, gave rise to conditioned medium, which reduced the clonogenic survival of reporter cells. However the influence of tumour tissue on this process was not examined.

There is evidence from earlier in vitro experiments by our group, that some tumour cells - particularly those which are radioresistant or have mutant or dysfunctional p53 do not produce death inducing bystander signals [50-53]. Two glioma cell lines which serve as experimental models for glioma in rodents were considered for these experiments; the F98 glioma cell line, which was developed in the Fisher rat and the C6 glioma cell line, which was originally developed in the Wistar rat [54-56]. The C6 line was used in the preliminary experiments [7]. There is a divergence of opinion in the literature concerning the p53 status of F98 cells with one author claiming they have wild type and another claiming mutant status [57,58]. The consensus at present is that the line F98 contains mutant p53. C6 cells are reported to have wild type p53 [56,59-61]. The results of several studies suggest that activating p53 expression using various drugs enhances apoptotic death after radiation exposure in both these cell lines, presumably because of dysfunctional operation of up-stream or downstream elements of the pathways involving p53 which should be activated following radiation exposure [58,62-66]. For these experiments the decision was made to use the F98 glioma cell line in Fisher rats so that the effect of a p53 mutant tumour could be examined.

In the experiments to be described here, F98 cells were stereotactically inoculated into the brain of Fisher rats. The rats were irradiated using the microbeam synchrotron radiation at the ESRF after which they were put in cages with unirradiated rats for $48 \mathrm{~h}$. Samples from all rats and various controls were taken and examined in a reporter assay for evidence of bystander signal production.

\section{Methods}

Animals

Male adult Fisher rats in the weight range 260-280 g (Charles River, France) were used as the animal model in our experiments. Animals were housed and cared for prior to the experiments by the ESRF Animal Facility in accordance with French and Canadian Animal Care Protocols.

\section{Tumour inoculation}

The F98 glioma cell line was selected for our studies because of its mutant p53 status and because it shares a wide range of characteristics with the highly malignant human brain tumour glioblastoma multiforme (GBM) [56]. Once injected into the brain, F98 glioma cells rapidly proliferate forming a solid, highly invasive malignant tumour, delineated by a rim of activated astrocytes and small groups of infiltrating tumour cells [56]. This tumour model has been used in multiple studies involving conventional radiotherapy and synchrotron radiation.

For these experiments, F98 cells were obtained from ATCC and maintained in T75 $\mathrm{cm}^{2}$ flasks using Dulbecco's Modified Eagle Medium (Gibco, France) supplemented with 10\% FBS (Gibco, France) and $5 \mathrm{ml}$ Penicillin-Streptomycin (Gibco, France). Cells from a $90 \%$ confluent culture were detached by incubation with $20 \mathrm{ml}$ of calcium and magnesium free Hank's Balanced Salt Solution (Gibco, France) for $20 \mathrm{~min}$ at $37{ }^{\circ} \mathrm{C}$ in an atmosphere of $5 \% \mathrm{CO}_{2}$ in air. The cell suspension was centrifuged at $1000 \mathrm{rpm}$ for $4 \mathrm{~min}$, the pellet was re-suspended in $1 \mathrm{ml}$ of fresh growth medium and cells were counted using a haemocytometer.

Fisher rats were subjected to general anaesthesia (2-2.5\% isofluorane in $2 \mathrm{~L} / \mathrm{min}$ compressed air) and placed in a stereotactic frame. An incision of $1-1.5 \mathrm{~cm}$ length was made on the scalp following the sagittal midline. A burr hole was placed in the skull over the right hemisphere, $3 \mathrm{~mm}$ to the right from the sagittal midline and $3 \mathrm{~mm}$ posterior from the coronal suture. Then 100,000 F98 cells suspended in $10 \mu \mathrm{l}$ were slowly injected into the brain $3 \mathrm{~mm}$ below the cortical surface over $4 \mathrm{~min}$, using an automated syringe pump (KDS 320, GENEQ). Once the injection was finished and the needle removed, the hole was sealed with bone wax and the incision was closed. Rats were maintained for 7 days to allow tumour development. 


\section{Irradiation}

In preparation for the irradiation, rats were deeply anesthetised using 3\% isofluorane in $2 \mathrm{~L} / \mathrm{min}$ compressed air and maintained with an intraperitoneal injection of a Ketamine-Xylazine cocktail (Ketamine: Xylazine = 1: 0.625; Ket 1000 and Paxman from Virback France). Animals were transported from the animal facility to the biomedical beamline ID17 in less than 5 min. Each irradiation group had 5 rats, which were individually positioned on the goniometer and the corresponding radiation dose for its treatment group was applied in anterior-posterior position to the tumour location in the right cerebral hemisphere by off-setting one edge of the irradiation field $2 \mathrm{~mm}$ towards the right from the midline (Fig. 1). The left nonirradiated cerebral hemispheres and the urinary bladder served as fields for study of abscopal effects in the directly irradiated animals. After irradiation, all rats were put in individual cages with a marked, unirradiated normal (tumour free) rat, meaning that 5 irradiated rats were matched with 5 non-irradiated rats for the study of bystander effects.

Animals irradiated in MRT mode were exposed in a single treatment session to 20 or 200 Gy skin-entry doses. The skin entrance dose corresponds to the peak dose at $3 \mathrm{~mm}$ depth and is determined as described hereafter. Absolute dose measurements for preclinical experiments are performed using a pinpoint ion chamber (PTW 31014) in a solid water phantom (Gammex) to measure the dose rate in $\mathrm{Gy} / \mathrm{s} / \mathrm{mA}$ for a $2 \mathrm{~cm} \times 2 \mathrm{~cm}$ field size at $2 \mathrm{~cm}$ depth. All corrections, like for temperature and pressure, the polarization between the electrodes, the calibration of the electrometer, a correction factor for our energy spectrum and the ion recombination correction according to the IAEA 398 protocol are included.

The peak skin entrance dose is then converted with the help of Monte Carlo pre-calculated output factors depending on the desired beam-size chosen for the irradiation. In order to translate the experimentally determined dose rate within the MRT GUI (Graphical user interface) into a vertical displacement to extend the 520 micron height microbeams into an array of 50 quasi-parallel $14 \mathrm{~mm}$ high rectangular planar microbeams, the MRT goniometer speed is calculated to deliver the desired peak entrance dose, depending on the electron current $(\mathrm{mA})$ in the storage ring. A $10 \mathrm{~mm}$ wide array of multichromatic beamlets was generated by a multislit collimator [67] with a mean energy of $105 \mathrm{keV}$ by filtering the white Synchrotron beam with several filters including $1.5 \mathrm{~mm}$ of Aluminium and $1 \mathrm{~mm}$ of Copper. The typical dose rate during

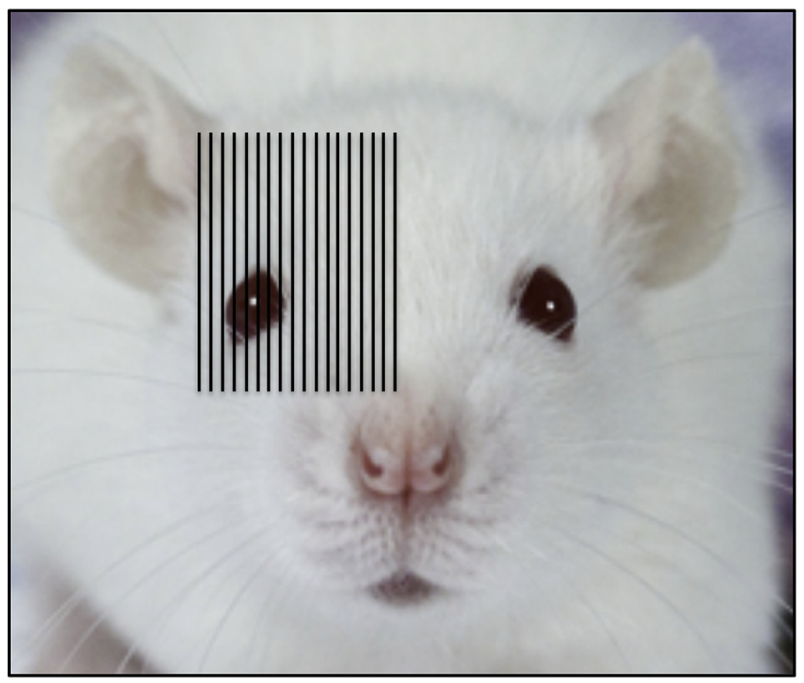

Figure 1. Graphical representation of the incident synchrotron microbeam. these experiments was $\sim 14,000 \mathrm{~Gy} / \mathrm{s}$. The valley dose is computed by Monte Carlo calculations and more recently a Treatment Planning System (TPS) with an analytical approach is used to calculate the valley dose based on CT data from a rat applying the irradiation parameters in these experiments $[68,69]$. Benchmarking of the calculated dose is still ongoing, but results with Gafchromic film dosimetry confirm an agreement within $10 \%$ between the computed and measured valley dose values [70].

Although multi-directional treatment is more successful in increasing survival, the geometry of the unidirectional beam works better for understanding bystander effects. Unidirectional irradiation creates a less complicated 3D geometrical pattern of dose peaks and dose valleys within the brain tissue than bidirectional irradiation and therefore makes it easier to study how the normal tissue between the microbeams is involved in the induction of bystander effects.

In order to determine whether scatter radiation places a role in the induction of bystander and abscopal responses, 5 rats and 5 cage mates were selected as scatter controls. A PTW semiflex ion chamber (PTW, Freiburg, Germany) was used to measure the scatter dose received at the urinary bladder after brain irradiation with 200 Gy delivered in MRT mode. The dose at the site of the urinary bladder was calculated as $3.31 \mathrm{mGy}$ for MRT. An X-ray generator was adapted with different additional filters to obtain an adequate dose rate, in order to deliver the whole body dose of 3.31 mGy to the rats. HD-610 and MD-55 Gafchromic Films (ISP Advanced Materials, http://online1.ispcorp.com/) were used to verify all irradiation doses and modalities applied.

Untreated controls stayed in the ESRF animal facility and never left the cage. One group received anaesthesia before euthanasia (sham control) and another group received no anaesthesia to exclude potential effects of the anaesthetic. These control rats were also paired with cage mates and were held two to a cage similar to the other experimental groups. We previously demonstrated that a sham irradiation did not induce abscopal effects or affect the protein expression of brain compared to controls [46].

All irradiated rats were transported back to the ESRF animal facility after irradiation. At $48 \mathrm{~h}$ after irradiation, the animals were deeply anesthetised, beheaded and dissected.

\section{Dissections and sampling for explant culture}

Dissection of the brain was performed in a biosafety cabinet. Two pieces of brain tissue (approximately $5 \mathrm{~mm} \times 5 \mathrm{~mm} \times 3 \mathrm{~mm}$ ) were taken from both the right and the left cerebral hemispheres using sterile instruments. The tissue sample from the right (irradiated) hemisphere was taken from the centre of the irradiation array and the sample from the left (unirradiated) hemisphere was taken from the corresponding contralateral location. Samples were placed in a $5 \mathrm{ml}$ sterile tube containing $1 \mathrm{~mL}$ of Roswell Park Memorial Institute (RPMI 1640, Gibco) growth medium, supplemented with $10 \%$ FBS, $5 \mathrm{ml}$ of Penicillin-Streptomycin (Gibco), $5 \mathrm{ml}$ of $\mathrm{L}-$ glutamine (Gibco), $0.5 \mathrm{mg} / \mathrm{ml}$ of Hydrocortisone (Sigma-Aldrich), and $12.5 \mathrm{ml}$ of $1 \mathrm{M}$ HEPES buffer solution (Gibco). Samples were immediately transported on ice to the tissue culture laboratory to be prepared for explant culture. The remaining brain tissue was snap-frozen in liquid nitrogen and stored at $-80{ }^{\circ} \mathrm{C}$ for proteomic studies. The entire extracted urinary bladder was also placed in a sterile $5 \mathrm{ml}$ tube containing $1 \mathrm{ml}$ of complete growth medium and used to set up tissue explant cultures.

\section{Explant tissue culture and culture medium harvest}

Explant tissue culture was performed in the biosafety level 2 laboratory of the ESRF biomedical beamline. Brain and urinary 
bladder tissues were cut in 3 equal-size pieces of approximately $2 \mathrm{~mm}^{3}$ in a biosafety cabinet. The pieces were plated as single explants in the centre of a $25 \mathrm{~cm}^{2}$ growth area in a $50 \mathrm{ml}$ volume flask (Falcon), containing $2 \mathrm{ml}$ of complete growth medium. Flasks were then placed in a tissue culture incubator set at $37{ }^{\circ} \mathrm{C}$, with an atmosphere of $5 \% \mathrm{CO}_{2}$ in air and $95 \%$ humidity left undisturbed for $24 \mathrm{~h}$. Growth medium from each of the three explant pieces (total approximately $5 \mathrm{ml}$ ) was harvested $24 \mathrm{~h}$ later by pouring it off into a sterile plastic container. This was then filtered through a sterile $0.22 \mu \mathrm{m}$ filter (Acrodisc Syringe Filter with HT Tuffryn Membrane, Pall Life Sciences) to ensure that cells or other debris were not present in the harvested medium, and placed in a $7 \mathrm{~mL}$ tube. Conditioned growth medium was kept in $4{ }^{\circ} \mathrm{C}$ until all media were collected and then transported to McMaster University for clonogenic reporter bioassays.

\section{Clonogenic reporter cell line}

HaCaT cells have been used as reporters for explanted tissue assays by our group in Canada and earlier in Ireland for over 15 years [71]. The cell line consists of epithelial cells, which became immortal spontaneously. They were derived originally from normal human skin from a patient with a melanoma [72] and have been used in a wide range of experiments due to their reliable and stable response to bystander signals. They show a reduction of around $40 \%$ in colony survival in response to addition of autologous irradiated cell conditioned medium (ICCM) over a wide range of donor cell radiation doses [73]. HaCaT cells have 3 p53 point mutations; 1 in codon 179 of exon 5 on one allele, and 2 consecutive mutations in codons 281 and 282 of exon 8 on the other allele [74]. In spite of its mutations, data show that p53 in HaCaT cells remains functional with respect to inducing apoptosis [75]. In our hands they behave like wild-type cells with respect to bystander effect reporting. Unlike true p53 mutant or null cells where signal is produced but the cells cannot respond to signal. This leads us to suspect that the critical p53 function in determining whether response to bystander signals happens, is located in the wild type codons.

The HaCaT cells were cultured in T75 flasks (Falcon) with RPMI 1640 supplemented as above. Once the cells reached about 90-95\% confluence they were detached using 1:1 (v:v) solution of $0.02 \%$ Trypsin/EDTA (1 mM) (Gibco) and Dulbecco's Phosphate-Buffered Solution (1x) (Gibco). The concentration of cells was determined using a Coulter Counter (Beckman Coulter model $Z_{n}$ ).

\section{Clonogenic HaCaT cell reporter bioassay}

Upon arrival at McMaster University, the conditioned medium harvested in France was transferred into $25 \mathrm{~cm}^{2}$ flasks containing the HaCaT reporter cells. Reporter flasks were seeded with 500 cells and set up $6 \mathrm{~h}$ prior to the medium transfer from T75 flasks which were 90-95\% confluent. Plating efficiency and medium transfer controls were also set up. The flasks were then placed in an incubator for 10-12 days to allow for colony formation using the Puck and Marcus technique [76]. Once colonies reached a suitable size they were stained using $2 \mathrm{~mL}$ of a 1:4 solution of Carbol Fuchsin in water.

Colonies were counted using a 50 cells threshold and the percentage survival fraction was calculated using the plating efficiency (PE) of the reporter cells as shown below:

Survival Fraction $=\frac{P E \text { of treated cells }}{P E \text { of control cells }} \times 100$
Fura-2 measurements to determine intracellular free calcium in HaCaT cells

The cells were seeded in glass bottomed dish (MatTek) at a density of approximately 500,000 cells and incubated at $37{ }^{\circ} \mathrm{C}$ and $5 \% \mathrm{CO}_{2}$ for $18-24 \mathrm{~h}$ prior to measurement to achieve $50 \%$ confluence. Cells were washed 3 times with buffer $(130 \mathrm{mM} \mathrm{NaCl}, 5 \mathrm{mM} \mathrm{KCl}$, $1 \mathrm{mM} \mathrm{Na}_{2} \mathrm{HPO}_{4}, 1 \mathrm{mM} \mathrm{CaCl}, 1 \mathrm{mM} \mathrm{MgCl} 2$ and $25 \mathrm{mM}$ Hepes (pH 7.4)) followed by incubation with $1 \mathrm{ml}$ of $8.2 \mu \mathrm{M}$ Fura-2/AM (aminopolycarboxylic acid which binds to free intracellular calcium) (Sigma) at $37^{\circ} \mathrm{C}$ for $30 \mathrm{~min}$. Cells were washed 3 times with buffer to remove residual Fura-2/AM and $300 \mu \mathrm{L}$ of fresh buffer added to the dish for imaging. An Olympus 1 X81 microscope was used with a 40X oil objective and Fura filter cube with $510 \mathrm{~nm}$ emission. Fura-2 was excited at 380 and $340 \mathrm{~nm}$ and the ratio images were recorded every $4 \mathrm{~s}$ for $5 \mathrm{~min}$ with addition of $100 \mu \mathrm{l}$ of ICCM or control media after a stable baseline was reached approaching $30 \mathrm{~s}$. All measurements were conducted in the dark at room temperature.

\section{Statistical analysis}

Data are presented as standard error of the mean for the specific $\mathrm{n}$ value of each experiment. Significance between and within groups was determined using the Tukey multi-comparison test after a two-way ANOVA. In all cases $p$ values $\leq 0.05$ were selected as significant. Pearson correlations and linear regressions were done using SPSS and Prism 6.0.

\section{Results}

The clonogenic assay reports the bystander signal strength measured as the ability of the signals to reduce the clonogenic survival of the well characterised keratinocyte cell line. Figure. 2 shows the signal strength from the directly irradiated right brain (1a) of normal and tumour bearing rats receiving 20 and $200 \mathrm{~Gy}$ irradiation from the MRT beam and the abscopal effects in the left brain (1b) and distant bladder (1c) in these animals. All the data are normalised to the relevant sham control. There was no significant effect of the anaesthesia on clonogenic survival (nonsignificant p-values for right brain, left brain and urinary bladder respectively: $\mathrm{p}=0.495 ; \mathrm{p}=0.989 ; \mathrm{p}=0.993)$. The statistical analyses were therefore performed between the sham irradiated and the irradiated groups. Because of the high doses used in these experiments and the reported low threshold dose for triggering bystander signalling in vitro [22-24], a control group was included which received a whole body dose equivalent to the highest calculated scatter dose of $3.31 \mathrm{mGy}$ after delivery of $200 \mathrm{~Gy}$ to the head. The data in Fig. 2a show that there was no statistically significant difference between the different controls. There is however a significant difference in signal strength between the controls and the healthy rats which received direct irradiation of $20 \mathrm{~Gy}$ or $200 \mathrm{~Gy}$ to the right brain. The effect on clonogenic survival after $200 \mathrm{~Gy}$ is similar to that seen after $20 \mathrm{~Gy}$ MRT. The effect of direct irradiation to the tumour bearing right brain (Fig. 2d) is much more visible showing a very strong effect on clonogenic survival of the reporter cells after $20 \mathrm{~Gy}$ and an even stronger suppression of clonogenic growth after $200 \mathrm{~Gy}$ irradiation. Looking at the effects of signals from the left brain hemisphere (Fig. 2b), which received only a scatter dose, it is apparent that the only statistically significant effect is from the healthy animals where the tumour bearing right brain received $20 \mathrm{~Gy}$ MRT. The 200 Gy signals from the healthy animal are weaker but still present although not statistically significant. No significant effects are seen from the tumour bearing rats (Fig. 2e) when compared to their own controls. The data for the distant urinary bladder are shown in Fig. 2c. Once again there are no significant 

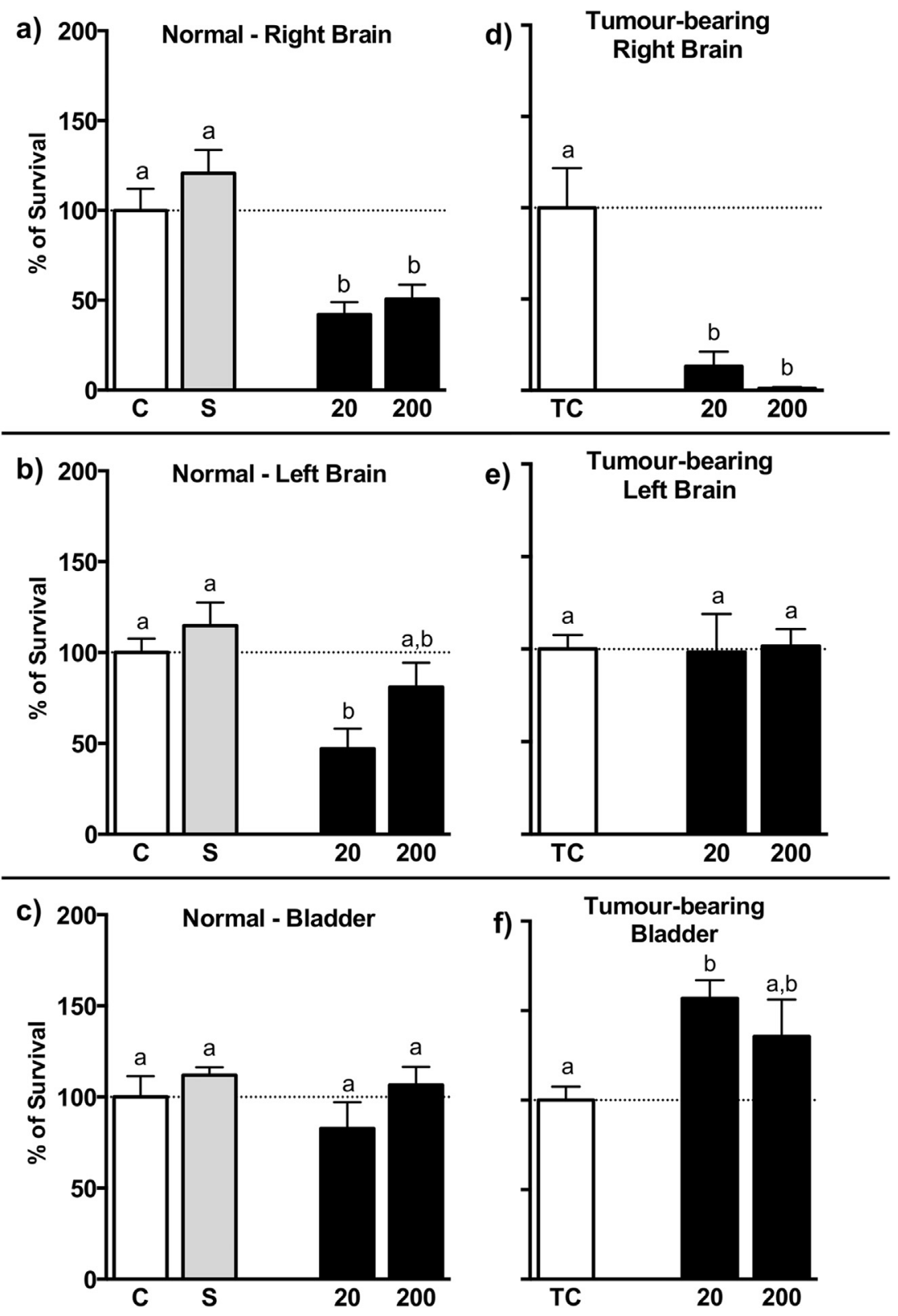

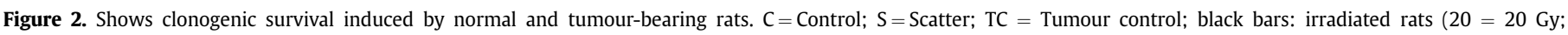
$200=200 \mathrm{~Gy}$ ). Letters a, b \& c indicate significant differences between groups. Error bars show SEM.

effects on clonogenic survival seen in the scatter group. The signals from the bladders of the $20 \mathrm{~Gy}$ irradiated healthy animals are not significantly different to those in the control group. However again the $20 \mathrm{~Gy}$ group signals are stronger than those in the $200 \mathrm{~Gy}$ group. When the tumour bearing animals are considered (Fig. 2f), it appears that relative to their own controls, the signals from the bladders of the groups receiving irradiation to the right brain are actually stimulating clonogenic survival.

Fig. 3 shows the results of the true bystander animals, which merely shared a cage for $48 \mathrm{~h}$ with irradiated rats. All the unexposed companion cage mates were tumour free but were paired with either a tumour bearing $(d-f)$ or a tumour free animal $(a-c)$. In Fig. 3a the clonogenic survival of reporter cells receiving signals from the right brain of the unirradiated cage mates is presented. Clearly the effect in the unexposed companion cage mate's right brain tissue is much stronger when they are paired with tumour free irradiated rats. When viewed in comparison to their own control, there are no significant differences in signal strength when the irradiated rats have tumours (Fig. 3d). The same pattern is seen when signal strength is monitored in left brain cage mate tissue (Fig. 3b, e). In the unexposed companion cage mates bladder (Fig. 3c), signal strength is not significantly different from the controls when the irradiated rat was tumour free but the tumour bearing rat bladder (Fig. 3f) signals stimulate the clonogenic survival of the reporter cells as was seen with the directly irradiated rats.

To better understand the overall influence of the presence of the tumour, Fig. 4 shows a comparison of the clonogenic survival of normal and tumour-bearing rats relative to the unirradiated normal control. Direct-irradiated normal rats (Fig. 4a) shows clearly the escalating decline in signal strength after 20 and $200 \mathrm{~Gy}$, which is significantly different from the normal control group in the right and left hemispheres after $20 \mathrm{~Gy}$, and only in the right hemisphere after 200 Gy. Direct-irradiated rats harbouring tumour showed a 

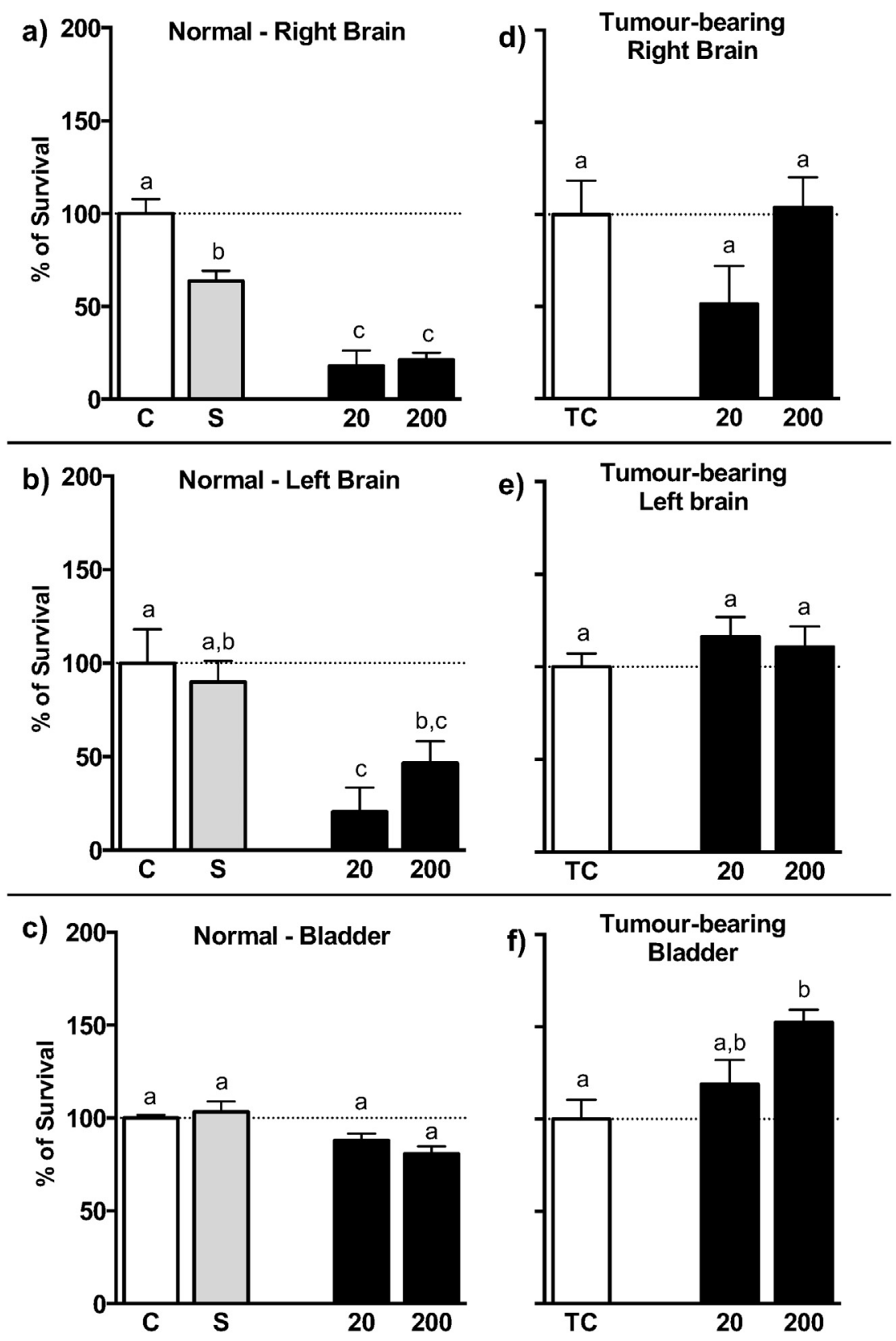

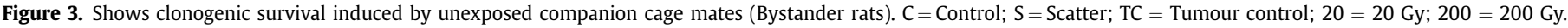
Letters a, b \& c indicate significant differences between groups. Error bars show SEM.

similar pattern of escalating decline in signal strength at 20 and $200 \mathrm{~Gy}$, but it was only significant in the right brain hemisphere. The unirradiated tumour control rats clearly induced a decrease in survival in the reporter cell line relative to the unirradiated normal control rats, and this decrease was significant in both right brain hemisphere and bladder.

The bystander animals (Fig. 4b) paired with normal irradiated rats show similar escalating decrease in survival at 20 and $200 \mathrm{~Gy}$, which is significant in all brain tissues but not in bladder. The bystander animals paired with tumour-bearing rats followed almost the same pattern as their direct-irradiated mates but the only significant group was $20 \mathrm{~Gy}$. The unirradiated tumour control rats also seemed to influence their cage mates but the decrease in clonogenicity was not significant.

The results of the calcium flux analysis are presented in Fig. 5(a-f) and Fig. 6(a-f) and on Table 1. The data show the relationship between the amount of clonogenic cell death in reporters and the calcium flux seen in the reporter cells. This is because calcium flux (measured as area under the curve) is usually considered to be the trigger, which induces the response pathway in the reporter cells. In Figs 5 and 6 the data were modelled with a linear regression between \% of cell death and Calcium flux induced by ICCM from irradiated and cage mate rats. Table 1 shows the Pearson Correlation statistics for these data. The conditioned medium from explants of the right brains of both normal and tumour bearing rats which were directly irradiated show weak positive, but statistically significant, correlations between the amount of clonogenic cell death of the reporter cells and the calcium flux in these cells. The right and left brains of unirradiated companion cage mates of normal rats without tumour show a very weak inverse correlation for right brain and a weak direct correlation for left brain which are statistically significant. Companion cage mates 

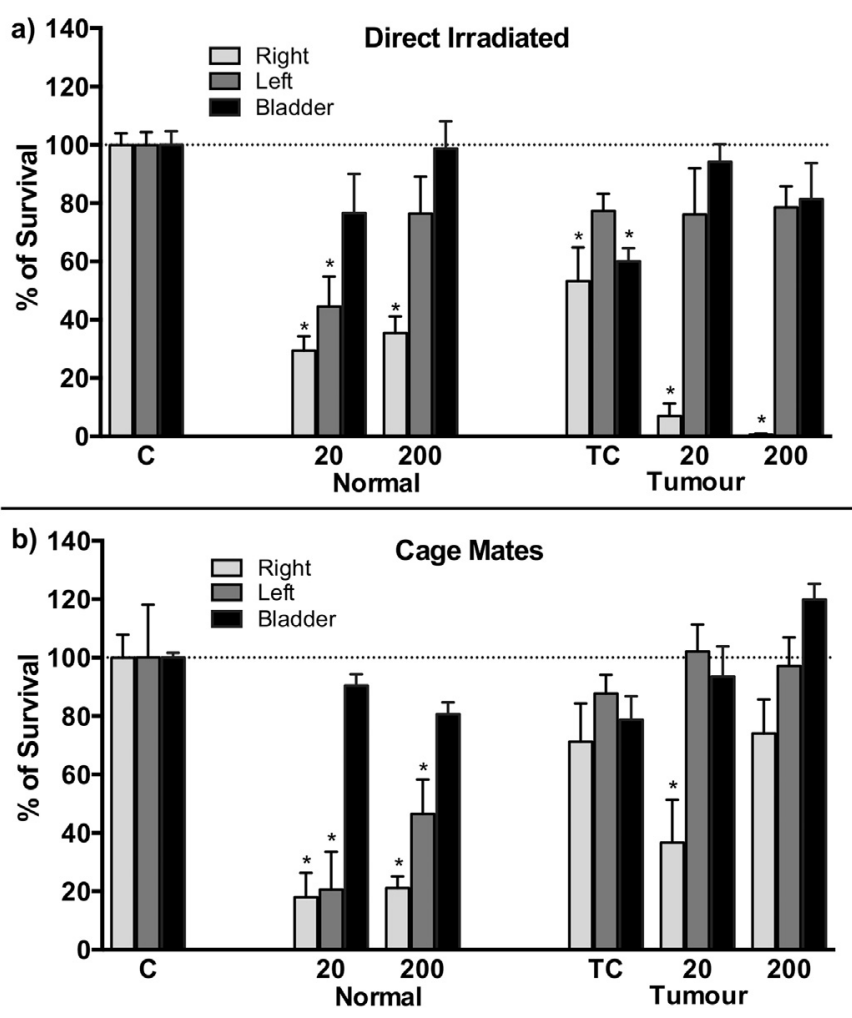

Figure 4. Comparison of clonogenic survival relative to the normal control. Letter "a" correspond to direct-irradiated rats, while "b" refers to the unirradiated Cage Mates or bystander animals. “*” Indicates significant difference against the unirradiated normal control rat. Error bars indicate SEM.

paired with animals with tumour show a negative significant correlation only in the left brains. None of the bladder tissues showed any significant effects.

\section{Discussion}

A key aim of this work was to look at the strength and type of signalling occurring within irradiated rats and between irradiated rats and their unexposed companion cage mates. This work builds on previously published data and preliminary results showing that there is a distinction between the effects of direct irradiation in an organism or a cell culture and the effects of the signals passed by that organism or cell culture to others. Clearly if the mechanisms of radiation action are to be fully understood, it is important to understand the signalling (indirect effects as well as the direct effects). The early literature on bystander effects was almost all concerned with effects in vitro [77]. These were mostly negative effects and the bystander effect was considered to be an extension of the negative effects of radiation. When in vivo experiments confirmed remote cell killing, transformation or mutational effects [78-80], the consensus was that bystander effects were bad and represented a spreading of the damage induced by the direct dose deposition. However there were also reports of adaptive responses [81-83]. These particularly occurred in cells treated with medium from irradiated cells before being themselves irradiated [84]. However, the groups using microbeams also occasionally reported adaptive and protective effects. Further extension of this to fish swimming with irradiated fish and tadpoles swimming with irradiated tadpoles $[26,27,85]$ suggested that bystander effects could be positive as well as negative. We consider this to be an important key for understanding radiotherapy outcomes.
The data presented here for normal Fisher rats and their cage mates contradicts those published for normal Wistar rats [7]. In the Wistar rat study, the abscopal effects in the directly irradiated rats became weaker as the distance from the targeted brain tissue increased. This was not attributable to declining scatter dose because the highest scatter dose calculated was given to rats as a whole body X-ray dose and had no effect. However in the unexposed companion cage mate group all the tissues in these unexposed animals produced the same response in the reporter cells. We thus deduced that the signals from the exposed animals produced a common systemic effect in the cage mates. The proteomic evidence [86] suggests this effect is protective. Similar proteomic data suggesting upregulation of protective proteins, were obtained with fish where irradiated fish were partnered with unirradiated fish [25]. In the experiments reported here however, while there are small effects induced in the left brain from the group in which the right brain was directly exposed to $20 \mathrm{~Gy}$, there are no significant signals from the bladder suggesting a weak or absent abscopal signalling mechanism. In the cage mates, it appears that the induced signalling is strongest in the right brain, weaker in the left brain and absent in the bladder. This suggests tissue specific signals rather than the homogeneous effect seen in the Wistar rats. We conclude that there must be a strain difference and draw attention to studies with CBA and C57Bl6 mice [87] where similar strain differences in production of and response to bystander signals were observed.

What is very evident in this study is that the presence of an F98 glioma in the directly irradiated rats prevents or counteracts the signalling in the other tissues of the rat and also in all the tissues of the tumour-free unexposed companions (cage mates). Moreover, instead of stimulating growth, the non-irradiated rats harbouring tumour induced a decrease in survival relative to the normal controls. This suggests that the presence of a tumour does not boost reporter cell growth; but it rather seems to counteract the bystander signal. In fact, in the bladder tissues, the inducible effect in both directly irradiated and cage mates that seems stimulatory is always under or near the $100 \%$ value of survival observed in the unirradiated normal control tissues (Fig. 4). Since the tumour develops from F98 cells implanted in the brain rather than evolving naturally over time within a supporting microenvironment, it is hard to argue that the animal's microenvironment is incapable of producing the signal. Most of the brain in the track of the microbeam is composed of normal tissue and in the healthy rats this produced signals. While strain and cell line differences in bystander signalling support the existence of a neutral or blocking effect associated with genomic instability [88], cancer phenotype [89], cancer susceptibility [90], mutant p53 [67,91,92] and radioresistance [93-95], this appears to be the first report that bystander effects in the healthy cage mate and abscopal effects in unirradiated tissues of the directly exposed rats can both be blocked by the presence of a glioma in the brain of the rat receiving direct irradiation. Our conclusion is that the presence of tumour in the brain actively counteracts signal production.

The work raises a number of key questions about non-targeted effects in vivo. First and most important is the lack of cell killing by bystander signals when the tumour is present in the directly irradiated brain. We hypothesize that this likely stems from antideath signals expressed by the tumour rather than absence of signals. Possibly the stress response pathways such as mitogenactivated protein kinases (MAPK), which are normally activated in response to radiation or receipt of bystander signals and which lead to apoptosis are somehow actively neutralised. Previous research [53] has demonstrated that mutant p53 cells are not able to respond to bystander signals although in the situation where p53 is mutated or knocked out, they can produce signals. In the model used here, 


\section{Normal}

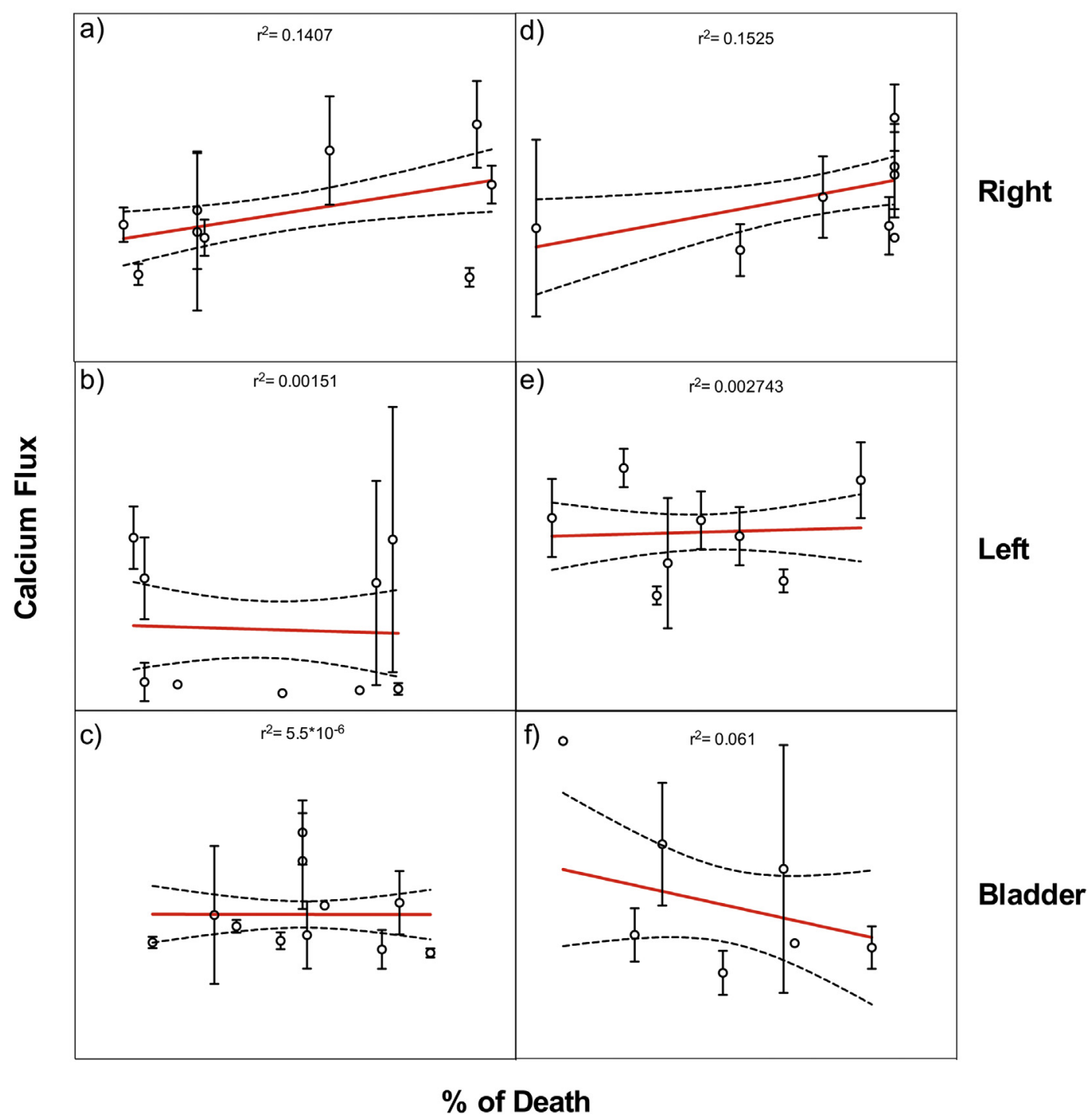

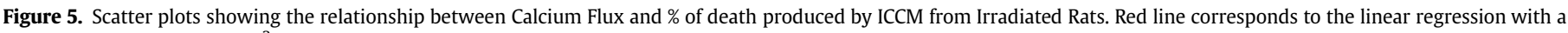

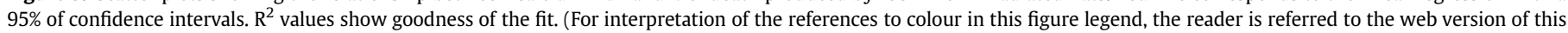
article.)

the host rat is p53 wild type but the inoculated tumour is mutant. Thus it is necessary to postulate that the secretion of a systemic signal from the tumour capable of "disarming" the stress sensing mechanisms in the normal cells would bypass apoptosis in the cells damaged by radiation. While it might be plausible to predict this in the directly irradiated rats it is difficult to see why this would be communicated to unirradiated healthy cage mates. However, in the literature, reference can be found to have whole body irradiation causing the secretion of volatiles, which make the irradiated rats socially unattractive to the cage mates [96]. The effects of the volatiles caused the cage mates to develop compromised immune responses [97,98]. Possibly, the irradiation of tumour tissue releases different volatiles, which neutralise the other bystander effects on the normal tissues as part of a strategy of the tumour to evade being attacked by the immune system. A key to resolving these questions might be to estimate the relative volume of tumour to normal tissue irradiated in the microbeam protocol.

Analysis of calcium flux in cells in vitro $[23,99]$ suggested that a sharp transient calcium flux triggered the response in cells receiving bystander signals. Investigation of various stress pathways suggested a role for the MAPK pathway leading to induction of apoptosis [34]. Therefore in these experiments calcium flux was measured to see if the flux was associated with reporter cell death where the tissue generating signals had or had not been directly irradiated. By analysing the directly irradiated rats and the unirradiated companion cage mates, we hoped to distinguish bystander effects in the companions from abscopal effects in the irradiated animal and to confirm a role for the presence of tumour cells in determining the response. As expected, the data in Table 1 do show positive correlations between death and calcium flux where the right brain tissue was directly irradiated. However the left brain and bladder tissues in the directly irradiated rats show no correlations either for normal or tumour bearing tissues. This suggests that the abscopal effects seen in these tissues are not related to the calcium flux pathway. Moreover, the calcium data versus \% of cell death from Table 1 shows significant positive correlations for the right brain, while the linear regressions show very low $\mathrm{r}^{2}$ values. Therefore, the biological significance of a linear relationship across 


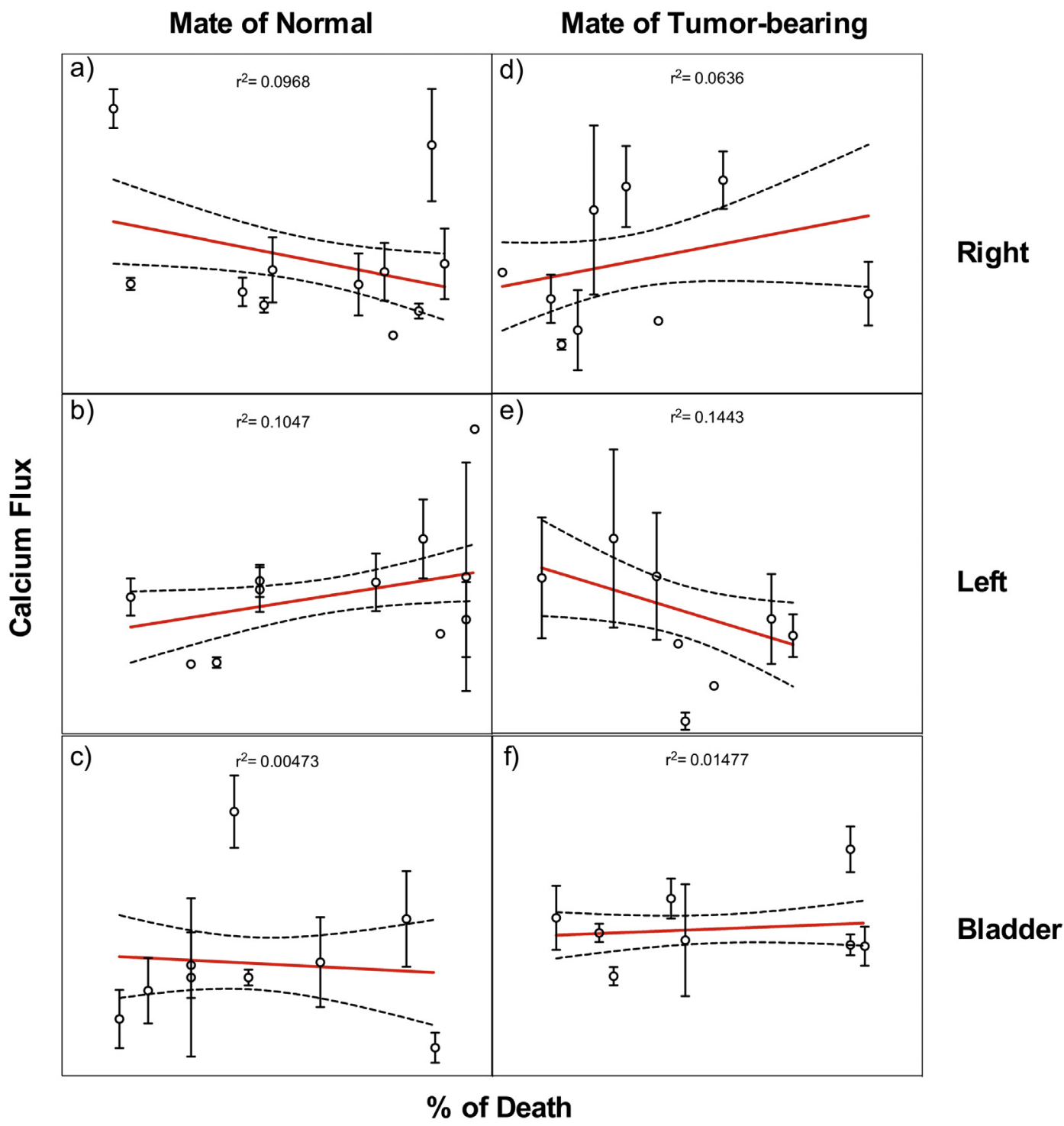

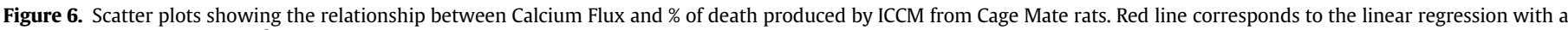

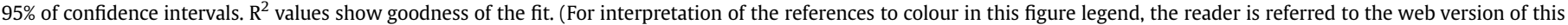
article.)

all doses may be spurious, a conclusion that extends to the cage mate data. The calcium flux versus fractional cell death data for the cage mates are much more difficult to explain. While companions of irradiated normal rats showed significant negative and positive

Table 1

Pearson Correlation between \% of cell death and Calcium flux induced by ICCM from irradiated and cage mate rats.

\begin{tabular}{llll}
\hline Group & Tissue & Pearson correlation & Significance (2-tailed) \\
\hline \multirow{2}{*}{ Normal } & Right & ${ }^{*} 0.375$ & $(0.014)$ \\
& Left & -0.39 & $(0.817)$ \\
\multirow{5}{*}{ Tumour } & Bladder & -0.02 & $(0.988)$ \\
& Right & ${ }^{*} 0.39$ & $(0.022)$ \\
\multirow{5}{*}{ Mate of normal } & Left & 0.052 & $(0.769)$ \\
& Bladder & -0.249 & $(0.264)$ \\
& Right & $*-0.311$ & $(0.037)$ \\
Mate of tumour & Left & ${ }^{*} 0.324$ & $(0.047)$ \\
& Bladder & -0.069 & $(0.681)$ \\
& Right & 0.252 & $(0.164)$ \\
& Left & $*-0.38$ & $(0.042)$ \\
& Bladder & 0.122 & $(0.501)$ \\
\hline
\end{tabular}

${ }^{*}$ Correlation is significant at the 0.05 level. correlations for the right and left brain respectively, the companion cage mate showed a reverse effect when a tumour was present in the irradiated rat. These observations suggest that the tumour modifies the pathways for abscopal and bystander effects. The data for the bladder explants from directly irradiated and unirradiated companion animals where the clonogenic survival suggested that the signals in the conditioned medium caused a significant positive growth stimulating effect reveal no correlation between calcium flux and growth stimulation. This again suggests that the pathways involved in the abscopal and bystander effects in these experiments do not involve the calcium flux which is associated with the directly irradiated right brain tissues. It is likely that downstream secondary signalling pathways are induced and that primary calcium signalling is confined to the tissue that actually received direct radiation energy deposition.

Another interesting result is the strain difference between Wistar and Fisher rats. While strain differences in radiation response are well known as was discussed earlier, this is a strain difference not just involving the tissues of the directly irradiated rats but involving the communication between the irradiated rats 
and their cage mates and the level of induced response in the cage mates. In one case the response is the same in all tissues of the cage mates but in the other it varies in the same way as the abscopal response. This could have major implications for research into individual radiosensitivity.

Finally since synchrotron microbeam irradiation is mainly tested in the treatment of aggressive brain tumours giving the therapist the opportunity to focus a very high X-ray dose in a small tissue volume in such a way that maximal protection of normal tissue is achieved, it is important to consider the implications of our findings for this type of therapy. Early use of MRT considered the peak and valley doses to be key to achieving normal tissue sparing $[44,100]$. The existence of bystander effects was well known and communication of bystander signals was considered in the field but not at all understood. In our experiments the peak entrance dose of $200 \mathrm{~Gy}$ to cells in the path of the beam is associated with a $20 \mathrm{~Gy}$ dose in the "valleys" between the microbeam tracks. Both these doses are several orders of magnitude larger than the in vitro threshold doses of around 2-3 mGy for triggering bystander effects. Bystander effects are known to saturate at a dose of about $0.5 \mathrm{~Gy}$ and a further increase in dose (at least up to $10 \mathrm{~Gy}$ ) does not increase the level of signal [101]. This means that bystander signalling will be saturated in the dose valleys as well as in the peak dose zones. In terms of impacts therefore, the question arises whether bystander signals from normal tissue are amplifying the harmful effects of radiation or are enabling beneficial effects and whether counter effects expressed by irradiated tumour cells (peak or valley) are having any effect. Both harmful and beneficial effects have been reported but the factors determining which response occurs are not known. Clearly more work is needed using biomarkers for damage such as $\gamma \mathrm{H} 2 \mathrm{AX}$ already identified as a useful marker [102] and for repair/protective effects using markers such as 53bp1 which indicate induction of repair [103].

In conclusion, the work reported here suggests that the presence of tumour tissue in the irradiated brain can modulate the abscopal effect in other organs of the directly irradiated animal and modify bystander response in unirradiated companion cage mates. The data taken together with earlier studies also suggest strain differences in these in vivo bystander responses. The implications for targeted radiotherapy using MRT are unknown and in need of further study.

\section{Acknowledgements}

We thank Dr. Géraldine Le Duc as leader of the ID 17 animal facility and Ms. Hélène Bernard for taking care of our animals during the irradiation experiments at the ESRF. Dr. E. Schültke holds an EU Marie Curie Reintegration Grant (PIRG-GA-2010-268250). The work has been performed with the support of the TD1205 "SYRA3" COST Action project and the ESRF funded proposal MD 736. We acknowledge support from the Canada Research Council Canada Research Chairs programme, The National Science and Engineering Research Council of Canada's Discovery Grant Programme and the Government of Chile for funding Cristian Fernandez-Palomo's PhD studies through Becas Chile.

\section{References}

[1] Mancuso M, Pasquali E, Giardullo P, Leonardi S, Tanori M, Di Majo V, et al The radiation bystander effect and its potential implications for human health. Curr Mol Med 2012;12:613-24.

[2] Blyth BJ, Sykes PJ. Radiation-induced bystander effects: what are they, and how relevant are they to human radiation exposures? Radiat Res 2011;176: 139-57.

[3] Munro AJ. Bystander effects and their implications for clinical radiotherapy J Radiol Prot 2009;29:A133-42.
[4] Tomita M, Maeda M. Mechanisms and biological importance of photoninduced bystander responses: do they have an impact on low-dose radiation responses. J Radiat Res 2014:1-15.

[5] Zeng J, Harris TJ, Lim M, Drake CG, Tran PT. Immune modulation and stereotactic radiation: improving local and abscopal responses. Biomed Res Int 2013;2013:658126.

[6] Kaminski JM, Shinohara E, Summers JB, Niermann KJ, Morimoto A, Brousal J. The controversial abscopal effect. Cancer Treat Rev 2005;31:159-72.

[7] Mothersill C, Fernandez-Palomo C, Fazzari J, Smith R, Schültke E, BräuerKrisch E, et al. Transmission of signals from rats receiving high doses of microbeam radiation to cage mates: an inter-mammal bystander effect. Dose Response 2014;12:72-92.

[8] O'Dowd C, Mothersill C, Cairns MT, Austin B, McClean B, Lyng FM, et al. The release of bystander factor(s) from tissue explant cultures of rainbow trout (Onchorhynchus mykiss) after exposure to gamma radiation. Radiat Res 2006;166:611-7.

[9] Mothersill C, Smith RW, Hinton TG, Aizawa K, Seymour CB. Communication of radiation-induced signals in vivo between DNA repair deficient and proficient medaka (Oryzias latipes). Environ Sci Technol 2009;43: $3335-42$.

[10] Audette-Stuart M, Yankovich T. Bystander effects in bullfrog tadpoles. Radioprotection 2012;46:S497.

[11] Mothersill C, Seymour C. Changing paradigms in radiobiology. Mutat Res 2012;750:85-95.

[12] Rastogi S, Coates PJ, Lorimore SA, Wright EG. Bystander-type effects mediated by long-lived inflammatory signaling in irradiated bone marrow. Radiat Res 2012;177:244-50.

[13] Yang G, Mei T, Yuan H, Zhang W, Chen L, Xue J, et al. Bystander/abscopal effects induced in intact arabidopsis seeds by low-energy heavy-ion radiation. Radiat Res 2008:170:372-80.

[14] Koturbash I, Zemp F, Kolb B, Kovalchuk O. Sex-specific radiation-induced microRNAome responses in the hippocampus, cerebellum and frontal cortex in a mouse model. Mutat Res 2011;722:114-8.

[15] Ilnytskyy Y, Koturbash I, Kovalchuk O. Radiation-induced bystander effects in vivo are epigenetically regulated in a tissue-specific manner. Environ Mol Mutagen 2009;50:105-13.

[16] Mancuso M, Pasquali E, Leonardi S, Rebessi S, Tanori M, Giardullo P, et al. Role of connexin43 and ATP in long-range bystander radiation damage and oncogenesis in vivo. Oncogene 2011;30:4601-8.

[17] Ruben JD, Smith R, Lancaster CM, Haynes M, Jones P, Panettieri V. Constituent components of out-of-field scatter dose for 18-MV intensity modulated radiation therapy versus 3-dimensional conformal radiation therapy: a comparison with 6-MV and implications for carcinogenesis. Int J Radiat Oncol Biol Phys 2014;90:645-53.

[18] Benadjaoud MA, Bezin J, Veres A, Lefkopoulos D, Chavaudra J, Bridier A, et al. A multi-plane source model for out-of-field head scatter dose calculations in external beam photon therapy. Phys Med Biol 2012;57:7725-39.

[19] Shields L, Vega-Carrascal I, Singleton S, Lyng FL, McClean B. Cell survival and DNA damage in normal prostate cells irradiated out-of-field. Radiat Res 2014;182(5):499-506.

[20] Butterworth KT, Redmond KM, McMahon SJ, Cole AJ, McCarthy HO, O'Sullivan JM, et al. Conventional in vivo irradiation procedures are insufficient to accurately determine tumor responses to non-uniform radiation fields. Int J Radiat Biol 2014:1-16.

[21] Schettino G, Folkard M, Michael BD, Prise KM. Low-dose binary behavior of bystander cell killing after microbeam irradiation of a single cell with focused C K X rays. Radiat Res 2005;163:332-6.

[22] Schettino G, Folkard M, Prise KM, Vojnovic B, Held KD, Michael BD. Low-dose studies of bystander cell killing with targeted soft $\mathrm{X}$ rays. Radiat Res 2003;160:505-11.

[23] Liu Z, Prestwich WV, Stewart RD, Byun SH, Mothersill CE, McNeill FE, et al. Effective target size for the induction of bystander effects in medium transfer experiments. Radiat Res 2007;168:627-30.

[24] Liu Z, Mothersill CE, McNeill FE, Lyng FM, Byun SH, Seymour CB, et al. A dose threshold for a medium transfer bystander effect for a human skin cell line. Radiat Res 2006:166:19-23.

[25] Smith RW, Wang J, Bucking CP, Mothersill CE, Seymour CB. Evidence for a protective response by the gill proteome of rainbow trout exposed to $\mathrm{X}$-ray induced bystander signals. Proteomics 2007:7:4171-80.

[26] Mothersill C, Smith RW, Agnihotri N, Seymour CB. Characterization of a radiation-induced stress response communicated in vivo between zebrafish. Environ Sci Technol 2007:41:3382-7.

[27] Mothersill C, Bucking C, Smith R, Agnihotri N, Oneill A, Kilemade M, et al. Communication of radiation-induced stress or bystander signals between fish in vivo. Environ Sci Technol 2006;40:6859-64.

[28] Isaeva VG, Surinov BP. Postradiation volatile secretion and development of immunosupression effectes by laboratory mice with various genotype. Radiats Biol Radioecol 2007;47:10-6.

[29] Surinov BP, Isaeva VG, Dukhova NN. Postirradiation volatile secretions of mice: syngeneic and allogeneic immune and behavioral effects. Bull Exp Biol Med 2004;138:384-6.

[30] Saroya R, Smith R, Seymour C, Mothersill C. Injection of resperpine into zebrafish, prevents fish to fish communication of radiation-induced bystander signals: confirmation in vivo of a role for serotonin in the mechanism. Dose Response 2009;8:317-30. 
[31] Singh H, Saroya R, Smith R, Mantha R, Guindon L, Mitchel REJ, et al. Radiation induced bystander effects in mice given low doses of radiation in vivo. Dose Response 2011;9:225-42.

[32] Poon RCC, Agnihotri N, Seymour C, Mothersill C. Bystander effects of ionizing radiation can be modulated by signaling amines. Environ Res 2007;105: 200-11.

[33] Mothersill C, Saroya R, Smith RW, Singh H, Seymour CB. Serum serotonin levels determine the magnitude and type of bystander effects in medium transfer experiments. Radiat Res 2010;174:119-23.

[34] Lyng FM, Maguire P, McClean B, Seymour C, Mothersill C. The involvement of calcium and MAP kinase signaling pathways in the production of radiationinduced bystander effects. Radiat Res 2006;165:400-9.

[35] Bräuer-Krisch E, Serduc R, Siegbahn EA, Le Duc G, Prezado Y, Bravin A, et al. Effects of pulsed, spatially fractionated, microscopic synchrotron Xray beams on normal and tumoral brain tissue. Mutat Res 2010;704: $160-6$.

[36] Slatkin DN, Spanne P, Dilmanian FA, Sandborg M. Microbeam radiation therapy. Med Phys 1992;19:1395-400.

[37] Blattmann H, Gebbers J-O, Bräuer-Krisch E, Bravin A, Le Duc G, Burkard W, et al. Applications of synchrotron X-rays to radiotherapy. Nucl Instruments Methods Phys Res Sect A Accelerators Spectrometers Detect Assoc Equip 2005;548:17-22.

[38] Dilmanian FA, Button TM, Le Duc G, Zhong N, Peña LA, Smith JAL, et al Response of rat intracranial 9L gliosarcoma to microbeam radiation therapy. Neuro Oncol 2002;4:26.

[39] Laissue JA, Bartzsch S, Blattmann H, Bräuer-Krisch E, Bravin A, Dalléry D, et al. Response of the rat spinal cord to X-ray microbeams. Radiother Oncol 2013;106:106-11.

[40] Dilmanian FA, Qu Y, Liu S, Cool CD, Gilbert J, Hainfeld JF, et al. X-ray microbeams: tumor therapy and central nervous system research. Nucl Instrum Methods Phys Res A 2005;548:30-7.

[41] Serduc R, Bouchet A, Bräuer-Krisch E, Laissue JA, Spiga J, Sarun S, et al. Synchrotron microbeam radiation therapy for rat brain tumor palliationinfluence of the microbeam width at constant valley dose. Phys Med Biol 2009;54:6711-24.

[42] Slatkin DN, Spanne P, Dilmanian FA, Gebbers JO, Laissue JA. Subacute neuropathological effects of microplanar beams of X-rays from a synchrotron wiggler. Proc Natl Acad Sci U. S. A 1995;92:8783-7.

[43] Dilmanian FA, Morris GM, Zhong N, Bacarian T, Hainfeld JF, Kalef-Ezra J, et al. Murine EMT-6 carcinoma: high therapeutic efficacy of microbeam radiation therapy. Radiat Res 2003;159:632-41.

[44] Dilmanian FA, Qu Y, Feinendegen LE, Peña LA, Bacarian T, Henn FA, et al. Tissue-sparing effect of $\mathrm{X}$-ray microplanar beams particularly in the CNS: is a bystander effect involved? Exp Hematol 2007;35:69-77.

[45] Fernandez-Palomo C, Schültke E, Smith R, Bräuer-Krisch E, Laissue J, Schroll C, et al. Bystander effects in tumor-free and tumor-bearing rat brains following irradiation by synchrotron X-rays. Int J Radiat Biol 2013;89: 445-53.

[46] Smith RW, Wang J, Schültke E, Seymour CB, Bräuer-Krisch E, Laissue JA, et al. Proteomic changes in the rat brain induced by homogenous irradiation and by the bystander effect resulting from high energy synchrotron X-ray microbeams. Int J Radiat Biol 2013;89:118-27.

[47] Schültke E, Trippel M, Bräuer-Krisch E, Renier M, Bartzsch S, Requardt H, et al. Pencilbeam irradiation technique for whole brain radiotherapy: technical and biological challenges in a small animal model. PLoS One 2013;8. e54960.

[48] Fernandez-Palomo C, Bräuer-Krisch E, Trippel M, Schroll C, Requardt H, Bartzsch S, et al. DNA double strand breaks in the acute phase after synchrotron pencil beam irradiation. J Instrum 2013;8:C07005.

[49] Schültke E, Juurlink BHJ, Ataelmannan K, Laissue J, Blattmann H, BräuerKrisch E, et al. Memory and survival after microbeam radiation therapy. Eur J Radiol 2008;68:S142-6.

[50] Ryan LA, Seymour CB, Joiner MC, Mothersill CE. Radiation-induced adaptive response is not seen in cell lines showing a bystander effect but is seen in lines showing HRS/IRR response. Int J Radiat Biol 2009;85:87-95.

[51] Mothersill C, Seymour CB, Joiner MC. Relationship between radiationinduced low-dose hypersensitivity and the bystander effect. Radiat Res 2002;157:526-32.

[52] Mothersill C, Seymour C. Cell-cell contact during gamma irradiation is not required to induce a bystander effect in normal human keratinocytes: evidence for release during irradiation of a signal controlling survival into the medium. Radiat Res 1998;149:256-62.

[53] Mothersill C, Bristow RG, Harding SM, Smith RW, Mersov A Seymour CB. A role for p53 in the response of bystander cells to receipt of medium borne signals from irradiated cells. Int J Radiat Biol 2011;87: $1120-5$.

[54] Ko L, Koestner A, Wechsler W. Characterization of cell cycle and biological parameters of transplantable glioma cell lines and clones. Acta Neuropathol 1980;51:107-11.

[55] Ko L, Koestner A, Wechsler W. Morphological characterization of nitrosourea-induced glioma cell lines and clones*. Acta Neuropathol 1980;51:23-31.

[56] Barth RF, Kaur B. Rat brain tumor models in experimental neuro-oncology: the C6, 9L, T9, RG2, F98, BT4C, RT-2 and CNS-1 gliomas. J Neurooncol 2009;94:299-312.
[57] Schlegel J, Piontek G, Kersting M, Schuermann M, Kappler R, Scherthan H, et al. The $\mathrm{p} 16 / \mathrm{Cdkn} 2 \mathrm{a} / \mathrm{Ink} 4 \mathrm{a}$ gene is frequently deleted in nitrosoureainduced rat glial tumors. Pathobiology 1999;67:202-6.

[58] Senatus PB, Li Y, Mandigo C, Nichols G, Moise G, Mao Y, et al. Restoration of p53 function for selective Fas-mediated apoptosis in human and rat glioma cells in vitro and in vivo by a p53 $\mathrm{COOH}$-terminal peptide. Mol Cancer Ther 2006;5:20-8.

[59] Yang S-H, Wang S-M, Syu J-P, Chen Y, Wang S-D, Peng Y-S, et al. Andrographolide induces apoptosis of C6 glioma cells via the ERK-p53-caspase 7PARP pathway. Biomed Res Int 2014;2014:312847.

[60] Asai A, Miyagi Y, Sugiyama A, Gamanuma M, Hong SH, Takamoto S, et al Negative effects of wild-type p53 and s-Myc on cellular growth and tumorigenicity of glioma cells. Implication of the tumor suppressor genes for gene therapy. J Neurooncol 1994;19:259-68.

[61] Strigari L, Mancuso M, Ubertini V, Soriani A, Giardullo P, Benassi M, et al Abscopal effect of radiation therapy: interplay between radiation dose and p53 status. Int J Radiat Biol 2014;90:248-55.

[62] Bencokova Z, Pauron L, Devic C, Joubert A, Gastaldo J, Massart C, et al. Molecular and cellular response of the most extensively used rodent glioma models to radiation and/or cisplatin. J Neurooncol 2008;86:13-21.

[63] Tada M, Matsumoto R, Iggo RD, Onimaru R, Shirato H, Sawamura Y, et al. Selective sensitivity to radiation of cerebral glioblastomas harboring p53 mutations. Cancer Res 1998;58:1793-7.

[64] Ikeda J, Tada M, Ishii N, Saya H, Tsuchiya K, Okaichi K, et al. Restoration of endogenous wild-type p53 activity in a glioblastoma cell line with intrinsic temperature-sensitive p53 induces growth arrest but not apoptosis. Int J Cancer 2001;94:35-43.

[65] Biston M-C, Joubert A, Adam J-F, Elleaume H, Bohic S, Charvet A-M, et al. Cure of fisher rats bearing radioresistant F98 glioma treated with cis-platinum and irradiated with monochromatic synchrotron X-rays. Cancer Res 2004:64:2317-23.

[66] Adam J-F, Joubert A, Biston M-C, Charvet A-M, Peoc'h M, Le Bas J-F, et al. Prolonged survival of Fischer rats bearing F98 glioma after iodine-enhanced synchrotron stereotactic radiotherapy. Int J Radiat Oncol Biol Phys 2006;64: 603-11.

[67] Bräuer-Krisch E, Requardt H, Brochard T, Berruyer G, Renier M, Laissue JA et al. New technology enables high precision multislit collimators for microbeam radiation therapy. Rev Sci Instrum 2009;80:074301.

[68] Bartzsch S, Lerch M, Petasecca M, Bräuer-Krisch E, Oelfke U. Influence of polarization and a source model for dose calculation in MRT. Med Phys 2014:41:041703.

[69] Bartzsch S, Oelfke U. A new concept of pencil beam dose calculation for 40 $200 \mathrm{keV}$ photons using analytical dose kernels. Med Phys 2013;40:111714.

[70] Bartzsch S, Tag J. Microbeam radiation therapy - physical and biological aspects of a new cancer therapy and development of a treatment planning system. 2014.

[71] Mothersill C, Rea D, Wright EG, Lorimore SA, Murphy D, Seymour CB, et al. Individual variation in the production of a "bystander signal" following irradiation of primary cultures of normal human urothelium. Carcinogenesis 2001;22:1465.

[72] Boukamp P, Popp S, Bleuel K, Tomakidi E, Bürkle A, Fusenig NE. Tumorigenic conversion of immortal human skin keratinocytes (HaCaT) by elevated temperature. Oncogene 1999;18:5638-45.

[73] Mothersill C, Seymour C. Medium from irradiated human epithelial cells but not human fibroblasts reduces the clonogenic survival of unirradiated cells. Int J Radiat Biol 1997;71:421-7.

[74] Lehman TA, Modali R, Boukamp P, Stanek J, Bennett WP, Welsh JA, et al. p53 mutations in human immortalized epithelial cell lines. Carcinogenesis 1993; $14: 833-9$.

[75] Henseleit U, Zhang J, Wanner R, Haase I, Kolde G, Rosenbach T. Role of p53 in UVB-induced apoptosis in human HaCaT keratinocytes. J Invest Dermatol 1997;109:722-7.

[76] Puck TT, Marcus PI. Action of x-rays on mammalian cells. J Exp Med 1956;103:653-66.

[77] Mothersill C, Seymour C. Radiation-induced bystander effects: past history and future directions. Radiat Res 2001;155:759-67.

[78] Sugihara T, Murano H, Nakamura M, Tanaka K. In vivo partial bystander study in a mouse model by chronic medium-dose-rate $\gamma$-ray irradiation. Radiat Res 2013:179:221-31.

[79] Chai Y, Calaf GM, Zhou H, Ghandhi SA, Elliston CD, Wen G, et al. Radiation induced COX-2 expression and mutagenesis at non-targeted lung tissues of gpt delta transgenic mice. Br J Cancer 2013;108:91-8.

[80] Hatzi VI, Laskaratou DA, Mavragani IV, Nikitaki Z, Mangelis A, Panayiotidis MI, et al. Non-targeted radiation effects in vivo: a critical glance of the future in radiobiology. Cancer Lett 2013;356(1):34-42.

[81] Nenoi M, Wang B, Vares G. In vivo radioadaptive response: a review of studies relevant to radiation-induced cancer risk. Hum Exp Toxicol 2014;34(3):272-83.

[82] Ko M, Lao X-Y, Kapadia R, Elmore E, Redpath JL. Neoplastic transformation in vitro by low doses of ionizing radiation: role of adaptive response and bystander effects. Mutat Res 2006;597:11-7.

[83] Staudacher AH, Blyth BJ, Lawrence MD, Ormsby RJ, Bezak E, Sykes PJ. If bystander effects for apoptosis occur in spleen after low-dose irradiation in vivo then the magnitude of the effect falls within the range of normal homeostatic apoptosis. Radiat Res 2010;174:727-31. 
[84] Maguire P, Mothersill C, McClean B, Seymour C, Lyng FM. Modulation of radiation responses by pre-exposure to irradiated cell conditioned medium. Radiat Res 2007;167:485-92.

[85] Audette-Stuart M, Kim SB, McMullin D, Festarini A, Yankovich TL, Carr J, et al. Adaptive response in frogs chronically exposed to low doses of ionizing radiation in the environment. J Environ Radioact 2011;102:566-73.

[86] Mothersill C., Smith R., Wang J., Fernandez-Palomo C., Fazzari J., Schültke E. et al.Proteomic analysis of brains from rats receiving high doses of microbeam irradiation and their cage mates, Int J Radiat Biol [Submitted (n.d.)].

[87] Mothersill C, Lyng F, Seymour C, Maguire P, Lorimore S, Wright E. Genetic factors influencing bystander signaling in murine bladder epithelium after low-dose irradiation in vivo. Radiat Res 2005;163:391-9.

[88] Chinnadurai M, Paul SFD, Venkatachalam P. The effect of growth architecture on the induction and decay of bleomycin and X-ray-induced bystander response and genomic instability in lung adenocarcinoma cells and blood lymphocytes. Int J Radiat Biol 2013;89:69-78.

[89] Akudugu JM, Azzam EI, Howell RW. Induction of lethal bystander effects in human breast cancer cell cultures by DNA-incorporated Iodine-125 depends on phenotype. Int J Radiat Biol 2012;88:1028-38.

[90] Lorimore SA, Mukherjee D, Robinson JI, Chrystal JA, Wright EG. Long-lived inflammatory signaling in irradiated bone marrow is genome dependent. Cancer Res 2011;71:6485-91.

[91] Lorimore SA, Rastogi S, Mukherjee D, Coates PJ, Wright EG. The influence of p53 functions on radiation-induced inflammatory bystander-type signaling in murine bone marrow. Radiat Res 2013;179:406-15.

[92] Kalanxhi E, Dahle J. The role of serotonin and p53 status in the radiationinduced bystander effect. Int J Radiat Biol 2012:88:773-6.

[93] Kashino G, Suzuki K, Kodama S, Watanabe M, Prise KM. Increased susceptibility to delayed genetic effects of low dose X-irradiation in DNA repair deficient cells. Int J Radiat Biol 2013;89:295-300.
[94] Mothersill C, Seymour RJ, Seymour CB. Increased radiosensitivity in cells of two human cell lines treated with bystander medium from irradiated repairdeficient cells. Radiat Res 2006;165:26-34.

[95] Mothersill C, Seymour RJ, Seymour CB. Bystander effects in repair-deficient cell lines. Radiat Res 2004;161:256-63.

[96] Frey B, Rubner Y, Kulzer L, Werthmöller N, Weiss E-M, Fietkau R, et al. Antitumor immune responses induced by ionizing irradiation and further immune stimulation. Cancer Immunol Immunother 2014;63:29-36.

97] M.R. Abramova, B.P. Surinov. Attractive and immunosuppressive properties of volatile secretions induced in mice separately and combine influence of ionizing radiation and cyclophosphamide. Radiats Biol Radioecol. $5074-80$.

[98] Mukherjee D, Coates PJ, Lorimore SA, Wright EG. Responses to ionizing radiation mediated by inflammatory mechanisms. J Pathol 2014;232: 289-99.

99] Lyng FM, Seymour C, Mothersill C. Initiation of apoptosis in cells exposed to medium from the progeny of irradiated cells: a possible mechanism for bystander-induced genomic instability? Radiat Res 2002;157:365-70.

[100] Tomita M, Maeda M, Maezawa H, Usami N, Kobayashi K. Bystander cell killing in normal human fibroblasts is induced by synchrotron X-ray microbeams. Radiat Res 2010;173:380-5.

[101] Seymour CB, Mothersill C. Relative contribution of bystander and targeted cell killing to the low-dose region of the radiation dose-response curve. Radiat Res 2000;153:508-11.

[102] Sokolov MV, Dickey JS, Bonner WM, Sedelnikova OA. Gamma-H2AX in bystander cells: not just a radiation-triggered event, a cellular response to stress mediated by intercellular communication. Cell Cycle 2007:6:2210-2.

[103] Tartier L, Gilchrist S, Burdak-Rothkamm S, Folkard M, Prise KM. Cytoplasmic irradiation induces mitochondrial-dependent 53BP1 protein relocalization in irradiated and bystander cells. Cancer Res 2007;67:5872-9. 